\title{
analisis Energi Pada Proses Pengolahan Teh Hitam Ortodoks (Studi Kasus PT. Perkebunan Nusantara VIII Kebun Gedeh, DeSa Sukamulya, Kecamatan Cugenang, Kabupaten Cianjur, JAWa Barat) \\ Energy Analysis On Ordodoks Black Tea Processing (Case Study in PT Perkebunan Nusantara VIII Kebun Gedeh, Sukamulya Village, Cugenang District, Cianjur Regency, West Java)
}

\author{
Totok Herwanto ${ }^{1)}$, Sarifah Nurjanah ${ }^{1)}$, Muhammad Saukat ${ }^{1)}$, Salman Hafidz ${ }^{2)}$, \\ ${ }^{1)}$ Staff Departemen Teknik Pertanian dan Biosistem, Fakultas Teknologi Industri Pertanian, \\ Universitas Padjadjaran \\ Jl. Bandung Sumedang Km 21, Jatinangor, Sumedang,Jawa Barat, Indonesia 40600 \\ ${ }^{2)}$ Alumnus Departemen Teknik Pertanian dan Biosistem, Fakultas Teknologi Industri Pertanian, \\ Universitas Padjadjaran \\ Jl. Bandung Sumedang Km 21, Jatinangor, Sumedang,Jawa Barat, Indonesia 40600 \\ Email : totok.herwanto@unpad.ac.id.
}

\begin{abstract}
ABSTRAK
Pada proses pengolahan teh membutuhkan energi yang cukup besar sehingga diperlukan suatu analisis sebagai upaya dalam menentukan strategi yang tepat terkait dengan penghematan energi pada rangkaian proses produksi teh hitam. Metode penelitian yang digunakan adalah metode analisis deskriptif menggunakan kuesioner, dimana analisis energi dihitung berdasarkan penggunaan energi pada setiap kegiatan dan menghitung konsumsi energi tenaga manusia dan energi sarana produksi lalu dideskripsikan melalui analisis SWOT. Hasil penelitian menunjukkan bahwa produksi teh hitam khususnya pada proses pengolahan dengan sistem ortodoks menggunakan masukan energi (tanpa energi tak langsung) 26.223,772 $\mathrm{MJ} /$ ton dan 73.034,359 MJ/ton (dengan energi tak langsung). Hasil analisis SWOT menunjukkan bahwa perusahaan masuk dalam kuadran I yaitu kondisi dimana perlunya strategi memanfaatkan peluang untuk meningkatkan kekuatan. Strategi dan peluang penghematan energi yang dapat dilakukan dalam proses pengolahan teh hitam ini adalah dengan cara memelihara dan memperbaiki sarana-prasarana pendukung proses pengolahan teh hitam ortodoks terutama pada mesin Heat Exchanger dan penggunaan listrik yang lebih bijak untuk dapat menekan jumlah penggunaan bahan bakar dan waktu proses pengolahan.
\end{abstract}

Kata kunci : Analisis energi, pengolahan teh, ortodoks

\begin{abstract}
In the process of tea processing requires considerable energy so that required an analysis as an effort in determining the appropriate strategy associated with energy savings in the series of black tea production process. The research method used is descriptive analysis method using questionnaire, where energy analysis is calculated based on energy usage in every activity and calculate human energy energy consumption and energy of production means then described by SWOT analysis. The results showed that black tea production, especially on processing with orthodox system uses energy input (without indirect energy) 26.223,772 MJ / ton and 73,034,359 MJ / ton (with indirect energy). The result of SWOT analysis shows that firms entering quadrant $I$ is a condition where the need for strategy to take advantage of opportunities to increase strength. Strategies and opportunities for energy savings that can be made in the processing of black tea is a way to maintain and improve infrastructure supporting processing of black tea orthodox mainly on the engine heat exchanger and the use of electricity more wisely in order to suppress the amount of fuel usage and processing time processing.
\end{abstract}

Keywords: Energy analysis, tea processing, orthodox

Diterima : 31 Agustus 2017 ; Disetujui : 28 September 2017; Online Published : DOI : $10.24198 /$ jt.vol12n1.7

Analisis Energi Pada Proses Pengolahan Teh Hitam Ortodoks (Studi Kasus PT. Perkebunan Nusantara VIII Kebun Gedeh, Desa Sukamulya, Kecamatan Cugenang, Kabupaten Cianjur, Jawa Barat) 


\section{PENDAHULUAN}

Energi menjadi bagian tak terpisahkan dari kebutuhan hidup masyarakat sehari-hari seiring dengan pesatnya peningkatan pembangunan di bidang teknologi, industri dan informasi. Peningkatan pembangunan di bidang teknologi mempengaruhi penggunaan alat dan mesin yang semakin meningkat khususnya dalam sistem pertanian di Indonesia. Menurut Inayah (2011), sistem pertanian yang semakin maju meningkatkan kebutuhan energi didalamnya. Hal ini ditandai dengan semakin banyaknya penggunaan alat dan mesin pertanian, penggunaan mesin proses produksi hasil pertanian yang semakin modern, pupuk dan pestisida serta bahan kimia lainnya.

Namun pelaksanaan penyediaan energi yang dilakukan oleh beberapa lembaga resmi yang ditunjuk oleh pemerintah untuk mengelola masalah energi di Indonesia, sampai saat ini masih belum dapat memenuhi kebutuhan masyarakat akan energi secara keseluruhan. Hal tersebut mengakibatkan terjadinya penurunan ketersediaan energi di Indonesia. Penurunan ketersediaan energi dapat dilihat dari semakin berkurangnya ketersediaan sumber daya energi fosil, khususnya minyak bumi, yang sampai saat ini masih merupakan tulang punggung dan komponen utama penghasil energi lainnya. Bahkan beberapa ahli berpendapat, bahwa dengan pola konsumsi seperti sekarang, maka dalam waktu 50 tahun cadangan minyak bumi dunia akan habis. Keadaan ini bisa diamati dengan kecenderungan meningkatnya harga minyak di pasar dalam negeri, serta ketidakstabilan harga tersebut di pasar internasional, karena beberapa negara maju sebagai konsumen minyak terbesar mulai melepaskan diri dari ketergantungannya kepada minyak bumi sekaligus berusaha mengendalikan harga, agar tidak meningkat (Lembaga Ilmu Pengetahuan Indonesia, 2004).

Konservasi energi merupakan salah satu cara yang penting baik untuk menurunkan laju penggunaan energi maupun emisi gas rumah kaca (GRK), serta berusaha mengurangi eksploitasi sumber-sumber energi. Konservasi energi dapat dirasakan dalam waktu yang relatif singkat. Selain itu konservasi energi di sektor industri akan mengurangi biaya produksi sehingga akan memperkuat daya saing produk yang dihasilkan. Konservasi energi dirasakan perlu karena pemakaian energi di Indonesia tergolong boros (Setiawan, 2010).

PT. Perkebunan Nusantara VIII (Persero), merupakan salah satu perusahaan yang berstatus sebagai Badan Usaha Milik Negara (BUMN) yang bisa menghasilkan keuntungan bagi negara. PTPN VIII memiliki komoditi usaha diantaranya komoditi teh, karet, kelapa sawit, kina dan kakao. Komoditi teh menjadi komoditi terbesar dimiliki oleh PTPN VIII.

Pengolahan teh yang dilakukan PTPN VIII melibatkan pekerja, alat dan mesin-mesin tua yang menggunakan berbagai bentuk energi. Dalam proses pengolahan teh diperlukan beberapa sumber energi antara lain tenaga manusia, biomassa, industrial diesel oil (IDO), listrik dan bahan bakar minyak. Akan tetapi PTPN VIII, sebagaimana BUMN lainnya, didirikan dengan tujuan menghasilkan laba untuk kepentingan negara mengalami banyak kendala diantaranya adalah kenaikan biaya produksi akibat kenaikan tarif dasar listrik dan bahan bakar minyak terutama industrial diesel oil dan bahan bakar minyak lainnya (Setiawan, 2010). Saat ini biaya produksi semakin mahal, sehingga mempersulit posisi perkebunan dan industri teh. PTPN VIII harus mencari solusi untuk menekan biaya produksi tersebut.

Bahan bakar padat berupa kayu bakar sudah lama menggantikan bahan bakar solar dan industrial diesel oil, meskipun tidak seluruhnya diganti akan tetapi hal ini merupakan salah satu usaha PTPN VIII untuk menekan biaya produksi, langkah lain yang dapat dilakukan untuk menekan biaya produksi adalah dengan cara menekan biaya energi melalui upaya penghematan energi. Sebelum melakukan upaya penghematan energi, perlu diketahuinya efisiensi energi dari proses pengolahan teh. Langkah untuk 
mengetahui efisiensi energi dapat dilakukan dengan cara menganalisis energi dari setiap tahap proses pengolahan teh.

Audit energi merupakan suatu langkah awal dalam pelaksanaan program konservasi energi. Tujuan adanya audit energi untuk mempelajari penggunaan energi pada suatu proses produksi yang meliputi jumlah, jenis dan sumber energi, aliran energi, dan biaya energi (Pimentel,1990).

Penelitian ini bertujuan untuk melakukan kajian mengenai pola konsumsi energi pada proses pengolahan, khususnya proses pengolahan komoditas teh. Sehingga menghasilkan pembuatan strategi dan peluang penghematan energi dengan mengubah atau memodifikasi kegiatan dalam suatu tahapan proses pengolahan teh hitam orotdoks.

\section{METODOLOGI}

Penelitian ini dilaksanakan pada bulan September 2016 sampai dengan Oktober 2016 bertempat di PT. Perkebunan Nusantara VIII Kebun Gedeh, Desa Sukamulya, Kecamatan Cugenang, Kabupaten Cianjur. Pengamatan dan pengumpulan data dilakukan terhadap kebutuhan energi untuk proses pengolahan mulai dari pengangkutan bahan baku pucuk hingga pengepakan berdasarkan jadwal kegiatan oleh pekerja, waktu yang diperlukan untuk setiap jenis kegiatan, jumlah tenaga kerja, jumlah dan jenis alat dan mesin yang digunakan, dan semua sarana produksi yang digunakan.

Setelah semua data yang dibutuhkan telah terkumpul, maka selanjutnya dilakukan konversi ke satuan energi. Dari hasil konversi kemudian dilakukan analisis yang merupakan tahapan pengolahan data yang diperoleh dari proses pengumpulan data. Pengolahan data dibedakan dalam 2 bagian yaitu penggunaan energi tanpa energi tak langsung alsintan dan penggunaan energi dengan energi tak langsung alsintan.

Setelah melakukan analisis, kemudian mendeskripsikan hasil analisa tersebut mengenai optimalisasi penggunaan energi pada proses pengolahan teh hitam ortodoks dengan menggunakan analisis SWOT yang merupakan sebuah metode perencanaan strategis yang digunakan untuk mengevaluasi kekuatan, kelemahan, peluang, dan ancaman dalam suatu proyek atau suatu spekulasi bisnis.

a) Kekuatan (Strength), yaitu kekuatan apa saja yang dimiliki sistem pengolahan teh hitam ortodoks. Dengan mengetahui kekuatan, bisa dilakukan efisiensi pada tahapan yang penggunaan energinya dapat direduksi.

b) Kelemahan (Weakness), yaitu segala faktor yang tidak menguntungkan atau merugikan bagi proses pengolahan teh hitam ortodoks yang dilakukan.

c) Kesempatan (Opportunities), yaitu semua kesempatan yang ada sebagai kebijakan pemerintah, peraturan yang berlaku atau kondisi yang sedang berlangsung.

d) Ancaman (Threats), yaitu segala sesuatu yang dapat mendatangkan kerugian bagi perusahaan dalam melakukan pengolahan teh hitam ortodoks.

Analisis SWOT membandingkan antara faktor eksternal peluang dan ancaman dengan faktor internal kekuatan dan kelemahan. Faktor internal dimasukkan ke dalam matrik yang disebut matrik faktor internal atau IFAS (Internal strategic Factor Analisis Summary). Faktor eksternal dimasukkan ke dalam matrik yang disebut faktor srategi eksternal atau EFAS (Eksternal strategic Factor Summary)(Rangkuti, 2004).

\section{HASIL DAN PEMBAHASAN}

Dalam penelitian ini jenis energi yang diperhitungkan meliputi semua proses pengolahan teh hitam ortodoks dimulai dari pengangkutan bahan baku pucuk hingga pengepakan. Energi yang diperhitungkan meliputi penggunaan energi yang berasal dari tenaga manusia, energi langsung bahan bakar untuk mengoperasikan peralatan pertanian, dan energi tidak langsung dari (embodied energi) dari alat mesin pertanian.

Secara umum proses pengolahan teh hitam ortodoks dibagi menjadi 7 tahapan 
kegiatan yaitu pengangkutan bahan baku pucuk, pelayuan, penggilingan, fermentasi, pengeringan, sortasi kering, dan pengepakan.

Penggunaan energi total pada proses pengolahan teh hitam ortodoks di PT. Perkebunan Nusantara VIII Kebun Gedeh, Desa Sukamulya, Kecamatan Cugenang, Kabupaten Cianjur sebesar 26.223,772 MJ/ton untuk penggunaan energi tanpa energi tak langsung alsintan dan 73.034,359 $\mathrm{MJ} /$ ton untuk penggunaan energi dengan energi tak langsung alsintan. Penggunaan energi tersebut dirinci menurut jenisnya dan dikelompokkan berdasarkan tahapan proses produksi dari pengangkutan bahan baku pucuk hingga pengepakan. Rincian penggunaan energi total untuk penggunaan energi tanpa energi tak langsung alsintan disajikan dalam Tabel 1 . Sedangkan untuk penggunaan energi dengan energi tak langsung alsintan disajikan dalam Tabel 2.

Tabel 1. Masukan energi proses pengolahan teh hitam ortodoks tanpa energi tak langsung alsintan

\begin{tabular}{clccccc}
\hline No. & Proses & $\begin{array}{c}\text { Energi } \\
\text { Manusia } \\
(\mathbf{M J} / \text { ton) }\end{array}$ & $\begin{array}{c}\text { Energi Bahan } \\
\text { Bakar } \\
(\mathbf{M J} / \text { ton) }\end{array}$ & $\begin{array}{c}\text { Energi Listrik } \\
(\mathbf{M J} / \text { ton) }\end{array}$ & $\begin{array}{c}\text { Total Energi } \\
\text { (MJ/ton) }\end{array}$ & Persentase \\
\hline 1. & Pengangkutan & 2,704 & 356,73 & 7,795 & 367,229 & $1,40 \%$ \\
2. & Pelayuan & 0,961 & $10.417,88$ & 744,094 & $11.162,93$ & $42,57 \%$ \\
3. & Penggilingan & 12,518 & - & 843,189 & 855,708 & $3,26 \%$ \\
4. & Fermentasi & 4,173 & - & 4,066 & 8,239 & $0,03 \%$ \\
5. & Pengeringan & 1,685 & $12.173,32$ & 311,163 & $12.486,17$ & $47,61 \%$ \\
6. & Sortasi Kering & 29,385 & - & 992,537 & $1.021,92$ & $3,90 \%$ \\
7. & Pengepakan & 13,185 & - & 308,386 & 321,572 & $1,23 \%$ \\
\hline & Total Energi $=$ & $\mathbf{6 4 , 6 1 2}$ & $\mathbf{2 2 . 9 4 7 , 9 3}$ & $\mathbf{3 . 2 1 1 , 2 3}$ & $\mathbf{2 6 . 2 2 3 , 7 7}$ & $\mathbf{1 0 0 \%}$ \\
\hline
\end{tabular}

Penggunaan energi yang terbesar adalah penggunaan energi pada proses pengeringan sebesar 12.486,168 MJ/ton pucuk teh penggunaan energi total untuk proses pengolahan teh hitam ortodoks. Besarnya energi yang digunakan untuk proses pengeringan dikarenakan banyaknya masukan energi yang digunakan, terutama pada bahan bakar padat yang digunakan meskipun dengan bantuan alat dan bahan bakar yang dapat mengurangi waktu kerja pengeringan. Secara keseluruhan penggunaan energi bahan bakar dengan nilai sebesar 22.947,928 $\mathrm{MJ} /$ ton merupakan energi terbesar yang digunakan pada proses pengolahan teh hitam ortodoks ini. Penggunaan jumlah bahan bakar yang lebih diefektifkan penggunaannya merupakan salah satu cara untuk lebih menghemat penggunaan energi terutama pada proses pengeringan dan pelayuan sehingga akan mengurangi penggunaan energi selama proses pengolahan berlangsung.

Tabel 2. Masukan energi proses pengolahan teh hitam ortodoks dengan energi tak langsung alsintan

\begin{tabular}{|c|c|c|c|c|c|c|c|c|}
\hline No. & Proses & $\begin{array}{c}\text { Energi } \\
\text { Manusia } \\
\text { (MJ/ton) }\end{array}$ & $\begin{array}{c}\text { Energi } \\
\text { Bahan } \\
\text { Bakar } \\
\text { (MJ/ton) }\end{array}$ & $\begin{array}{l}\text { Energi } \\
\text { Listrik }\end{array}$ & $\begin{array}{c}\text { Energi } \\
\text { Tak } \\
\text { Langsung } \\
\text { Alat } \\
\text { (MJ/ton) }\end{array}$ & $\begin{array}{c}\text { Energi } \\
\text { Tak } \\
\text { Langsung } \\
\text { Mesin } \\
\text { (MJ/ton) }\end{array}$ & $\begin{array}{l}\text { Total } \\
\text { Energi } \\
\text { (MJ/ton) }\end{array}$ & Persentase \\
\hline 1. & Pengangkutan & 2,704 & 356,73 & 7,795 & 107,628 & 175,224 & 650,082 & $0,89 \%$ \\
\hline 2. & Pelayuan & 0,961 & $10.417,88$ & 744,094 & 71,912 & $11.267,79$ & $22.502,63$ & $30,81 \%$ \\
\hline 3. & Penggilingan & 12,518 & - & 843,189 & 272,425 & $3.680,50$ & $4.808,64$ & $6,58 \%$ \\
\hline 4. & Fermentasi & 4,173 & - & 4,066 & 544,851 & 2,82 & 555,909 & $0,76 \%$ \\
\hline 5. & Pengeringan & 1,685 & $12.173,32$ & 311,163 & 440,476 & $4.525,08$ & $17.451,73$ & $23,90 \%$ \\
\hline 6. & Sortasi Kering & 29,385 & - & 992,537 & $11.930,11$ & $7.888,55$ & $20.840,59$ & $28,54 \%$ \\
\hline 7. & Pengepakan & 13,185 & - & 308,386 & 655,141 & $5.248,07$ & $6.224,79$ & $8,52 \%$ \\
\hline
\end{tabular}

Analisis Energi Pada Proses Pengolahan Teh Hitam Ortodoks (Studi Kasus PT. Perkebunan Nusantara VIII Kebun Gedeh, Desa Sukamulya, Kecamatan Cugenang, Kabupaten Cianjur, Jawa Barat) 
$\begin{array}{llllllll}\text { Total Energi }= & 64,612 & 22.947,93 & 3.211,23 & 14.022,55 & 32.788,04 & 73.034,36 & 100 \%\end{array}$

Penggunaan energi yang terbesar tetap langsung alat dan mesin) dengan rata-rata hasil sama seperti pada saat penggunaan energi tanpa memasukkan energi tak langsung yaitu penggunaan energi pada proses pelayuan sebesar 22.502,633 $\mathrm{MJ} /$ ton pucuk teh dari penggunaan energi total untuk proses pengolahan teh hitam ortodoks. Penggunaan jumlah alat dan mesin mengakibatkan energi tak langsung alsintan menjadi penyumbang energi terbesar pada masukan energi total. Perawatan rutin terhadap alat dan mesin merupakan salah satu cara untuk lebih menghemat penggunaan energi sehingga akan mengurangi resiko kerusakan alsintan selama proses pengolahan berlangsung.

Penggunaan energi total untuk pengolahan teh hitam ortodoks di PT. Perkebunan Nusantara VIII Kebun Gedeh sebesar 26.223,772 MJ/ton (tanpa energi tak langsung alat dan mesin) dengan rata-rata hasil panen 8,128 ton/hari, apabila dibandingkan dengan kebun lain di PT. Perkebunan Nusantara VIII berdasarkan hasil penelitian Taopik Setiawan (2010) di Perkebunan Cisaruni memiliki perbedaan yang signifikan yaitu $33.618 \mathrm{MJ} /$ ton (tanpa energi tak

panen 8,910 ton/hari. Dapat disimpulkan bahwa jika dengan rata-rata hasil panen 8,128 ton pada Kebun Cisaruni penggunaan energi menjadi $30.675 \mathrm{MJ} /$ ton, Kebun Gedeh lebih hemat dalam menggunakan energi untuk pengolahan teh hitam ortodoks sekitar 4.451 $\mathrm{MJ} /$ ton.

Pendekatan kuantitatif analisis SWOT berdasarkan pengamatan lapangan yang dilakukan di PT. Perkebunan Nusantara VIII Kebun Gedeh, Desa Sukamulya, Kecamatan Cugenang, Kabupaten Cianjur. Setelah mengetahui kekuatan, kelemahan, peluang, dan ancaman yang ada di PT. Perkebunan Nusantara VIII Kebun Gedeh, selanjutnya adalah melakukan analisis terhadap faktorfaktor tersebut dimana didapat hasil pengurangan $\mathrm{S}-\mathrm{W}$ sebagai sumbu $\mathrm{X}$ dengan nilai positif sebesar 4,2 dan faktor O-T sebagai sumbu $\mathrm{Y}$ dengan nilai positif sebesar 1,2. Untuk menentukan strategi yang digunakan agar proses pengolahan dapat berlangsung lebih efisien dapat digunakan kuadran SWOT sebagai berikut:

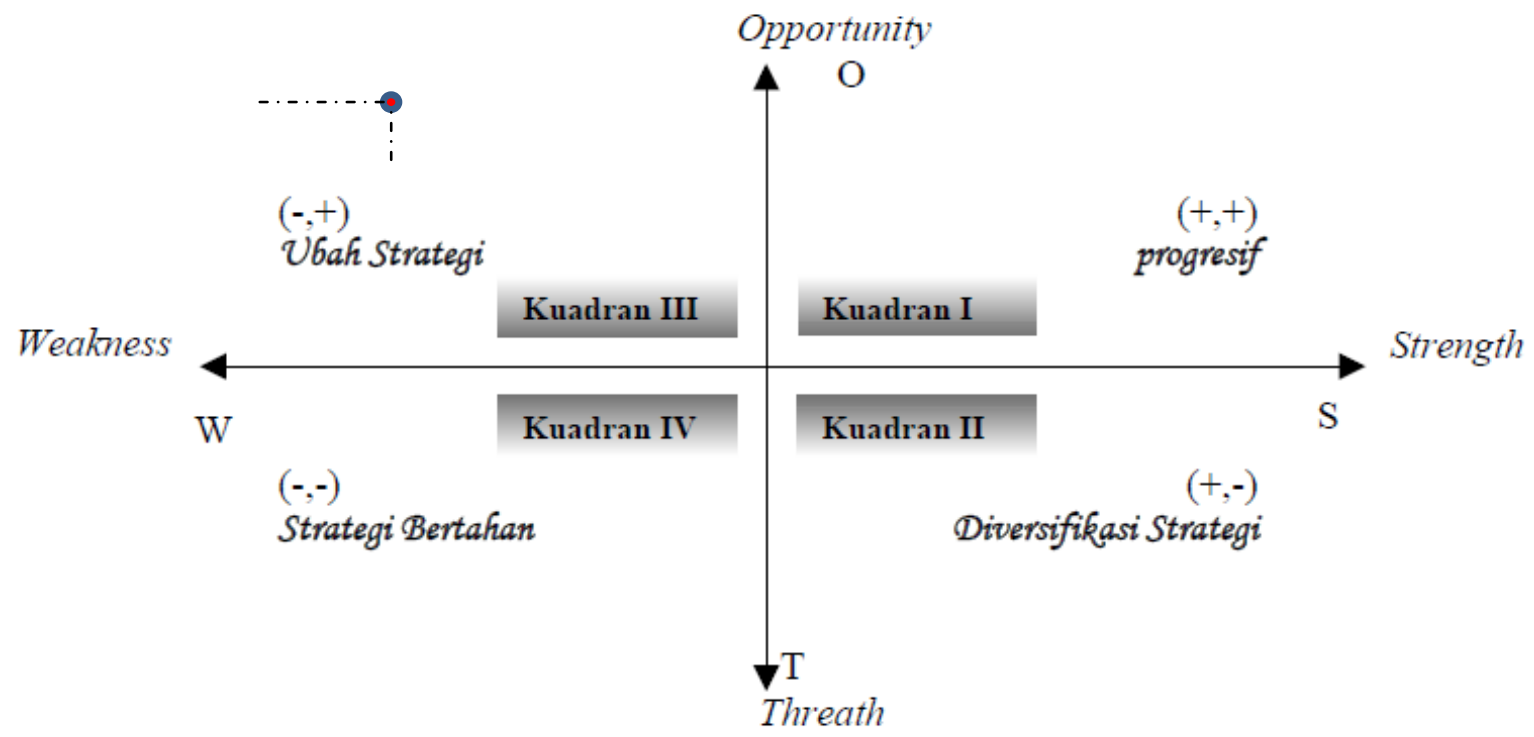

Gambar 1. Kuadran SWOT

Hal ini menandakan strategi PT. berada pada kuadran I yang artinya strategi Perkebunan Nusantara VIII Kebun Gedeh yang telah berlangsung di PT. Perkebunan 
Nusantara VIII Kebun Gedeh kuat. Strategi yang selama ini digunakan berada dalam kuadran 1 yaitu strategi SO, dimana solusi yang diberikan adalah dengan cara mempertahankan strategi dengan cara memanfaatkan peluang yang ada serta meningkatkan sistem yang telah berlangsung. Adapun langkah-langkah yang harus dilakukan sebagai berikut:

a) Perbaikan infrastruktur seperti jalan dan bangunan harus segera dilakukan mengingat jalan dan bangunan adalah prasarana penunjang pada proses pengolahan teh hitam karena dapat mempengaruhi proses pengolahan.

b) Pemeliharaan alat dan mesin pengolahan serta perbaikan terhadap mesin yang mengalami kerusakan perlu ditingkatkan karena hal tersebut dapat memperbaiki efisiensi kerja mesin, sehingga dapat lebih meningkatkan standar mutu pengolahan pabrik (SOP) dan kualitas teh hitam yang diproduksi.

c) Kepercayaan untuk mengolah hasil panen dari kebun Gunung Mas menjadi peluang yang sangat baik untuk mengatasi ancaman terhadap produksi yang menurun karena cuaca yang tak menentu, kerusakan tanaman teh oleh hama, dan pertumbuhan pucuk yang lambat, serta dapat menjaga kebutuhan bahan baku untuk produksi teh hitam ortodoks.

Solusi yang diberikan di atas merupakan solusi strategi secara umum. Dengan diketahuinya strategi yang digunakan yaitu SO maka hal yang dilakukan adalah memanfaatkan peluang yang ada untuk meningkatkan kekuatan yang terdapat di PT. Perkebunan Nusantara VIII Kebun Gedeh.

Konservasi energi merupakan usaha untuk memelihara dan melestarikan sumber energi yang ada sehingga tidak terjadi pemborosan energi yang berarti dan membawa dampak yang tidak baik dalam suatu industri atau perusahaan. Konservasi energi bermanfaat bukan hanya untuk menekan konsumsi dan biaya konsumsi energi, namun juga memberikan dampak yang lebih baik terhadap lingkungan.
Pada proses pengolahan, beberapa usaha penghematan energi yang dapat dilakukan adalah secara teknis maupun non teknis. Secara teknis yang dapat dilakukan antara lain: pemeliharaan dan perbaikan peralatan dan mesin secara teratur, memodifikasi mesin pemanen pucuk menjadi motor listrik untuk meningkatkan kualitas pucuk teh segar, penggantian peralatan yang bekerja di luar karakteristik kerja dan umur kerja (peremajaan) serta perbaikan pada prasarana penunjang proses pengolahan seperti jalan dari kebun menuju pabrik pengolahan dan bangunan pabrik pengolahan. Sedangkan non teknis adalah dengan melakukan pelatihan atau pembinaan para pekerja untuk menggunakan peralatan dan mesin secara tepat dan benar sesuai standar operasional serta menanamkan pengertian pentingnya penghematan energi.

\section{a) Peluang Penghematan Energi Bahan Bakar Padat Pada Proses Pelayuan}

Pada proses pengolahan teh hitam ortodoks di PT. Perkebunan Nusantara VIII Kebun Gedeh, konsumsi energi pada proses pelayuan adalah $42,57 \%$ (tanpa energi tak langsung) dari keseluruhan masukkan energi. Efisiensi pada proses pelayuan adalah $17,51 \%$ dengan efisiensi mesin withering trough sebesar $79,73 \%$ dan efisiensi mesin heat exchanger sebesar $21,96 \%$. Nilai ini bisa dikatakan tidak efisien karena sangat jauh dari angka 100\%. Dari nilai penggunaan energi pada proses pelayuan (tanpa energi tak langsung), 93,33\% berasal dari bahan bakar padat dan $6,66 \%$ dari listrik. Meskipun penggunaan energi bahan bakar kayu lebih besar, namun secara ekonomi lebih murah dibanding dengan energi listrik karena kayu diperoleh dengan mudah.

Energi bahan bakar padat ini dikonsumsi oleh mesin heat exchanger. Energi yang dihasilkan berupa energi untuk memanaskan bahan dan energi untuk menguapkan air. Laju penggunaan bahan bakar kayu adalah 254-365 kg/jam. Penggunaan bahan bakar kayu tergantung pada kadar air dan jenis kayu yang digunakan, karena itu akan berpengaruh 
terhadap efektifitas panas yang dihasilkan. Selain itu juga dipengaruhi kebersihan pipa udara dalam heat exchanger nya.

Prinsip kerja HE (heat exchanger) adalah memanaskan pipa api dengan udara panas dari tungku pembakaran. Tahapnya adalah panas dialihkan dari tungku kepada dinding pipa api, panas memasuki dinding pipa api dan dialihkan dari dinding pipa api ke udara. Udara bersih di luar pipa api yang telah panas dihisap main fan melewati pipa distribusi menuju blower dan selanjutnya dialirkan ke palung pelayuan.

Pemberian udara panas pada proses pelayuan tidak mutlak digunakan karena tergantung dari faktor kelembaban luar. Namun pada kenyataanya pemberian udara panas tetap dilakukan karena apabila hanya menggunakan udara luar maka proses pelayuan akan berjalan lebih lama. Usaha penghematan energi pada proses pelayuan dapat dilakukan dengan menggunakan udara luar sebelum pucuk diberi udara panas untuk aerasi. Pemberian udara panas untuk mencapai suhu udara pelayuan yang dikehendaki harus terkontrol agar tidak sampai menaikan suhu pelayuan terlalu tinggi sehingga terjadi penggunaan bahan bakar yang berlebihan. Selain itu, harus dilakukan upaya pembersihan terhadap peralatan dan mesin serta kontrol terhadap kebocoran pada pipa distribusi maupun area sekeliling blower palung pelayuan yang selama ini tidak dilakukan secara rutin.

Penggunaan bahan bakar kayu padat secara ekonomi lebih menguntungkan dibandingkan dengan solar (IDO) bagi perkebunan karena kayu didapatkan secara mudah dan murah. Dari sisi keamanan cadangan energi, penggunaan kayu akan menghemat cadangan minyak bumi.

b) Peluang Penghematan Energi Bahan Bakar Padat Pada Proses Pengeringan

Pada proses pengolahan teh hitam ortodoks di PT. Perkebunan Nusantara VIII Kebun Gedeh, konsumsi energi pada proses pengeringan adalah $47,61 \%$ (tanpa energi tak langsung) dari keseluruhan masukkan energi. Efisiensi pada proses pengeringan adalah 21,2\% dengan efisiensi mesin TSD sebesar $36,45 \%$ dan efisiensi mesin heat exchanger sebesar $58,15 \%$. Nilai ini bisa dikatakan kurang efisien karena masih jauh dari angka $100 \%$. Dari nilai penggunaan energi (tanpa energi tak langsung), 97,49\% berasal dari bahan bakar padat dan 2,5\% dari listrik. Pengeringan di PT. Perkebunan Nusantara VIII Kebun Gedeh menggunakan mesin pengering TSD dengan suhu udara masuk mesin pengering berkisar $95-105^{\circ} \mathrm{C}$ dan udara keluar berkisar 45-55 ${ }^{\circ} \mathrm{C}$. Penggunaan bahan bakar padat harus selalu dikontrol. Jika kayu tidak didorong masuk lebih dalam ke tungku maka suhu akan turun.

Penggunaan bahan bakar kayu dipengaruhi oleh tingkat kekeringan kayu tersebut. Kayu dengan kadar air tinggi akan mengakibatkan korosi pada pipa udara (heat exchanger) dan cerobong. Upaya menjaga bahan bakar kayu agar selalu dalam keadaan kering atau kadar air rendah.

Panas yang dihasilkan dari pembakaran kayu adalah panas yang dibutuhkan untuk mengeringkan kadar air yang terkandung dalam kayu tersebut dan panas yang digunakan untuk mengeringkan bubuk teh. Prinsip kerja HE adalah memanaskan pipa api dengan udara panas dari tungku pembakaran. Tahapnya adalah panas dialihkan dari tungku kepada dinding pipa api, panas memasuki dinding pipa api dan dialihkan dari dinding pipa api ke udara. Udara bersih di luar pipa api yang telah panas dihisap main fan menuju mesin two stage dryer.

Penghematan energi yang dapat dilakukan pada proses pengeringan adalah dengan cara perawatan dan penggantian bagian peralatan yang mengalami kerusakan pada heat exchanger. Perawatan yang perlu dilakukan adalah membersihkan debu dari hasil pembakaran kayu, membongkar heat exchanger dan mengontrol kebocoran agar hasil pembakaran pada burner tidak masuk bersama udara panas pada saat pengeringan. 


\section{KESIMPULAN}

Penggunaan energi untuk perhitungan tanpa energi tak langsung terbagi menjadi 7 tahap kegiatan pada proses pengolahan teh hitam ortodoks yaitu pengangkutan bahan baku pucuk teh sebesar 367,229 MJ/ton, pelayuan sebesar 11.162,934 MJ/ton, penggilingan sebesar 855,708 MJ/ton, fermentasi sebesar 8,239 MJ/ton, pengeringan sebesar 12.486,168 MJ/ton, sortasi kering sebesar 1.021,922 MJ/ton, dan pengepakan sebesar 321,572 MJ/ton.

Penggunaan energi untuk perhitungan dengan energi tak langsung terbagi menjadi 7 tahap kegiatan pada proses pengolahan teh hitam ortodoks yaitu pengangkutan bahan baku pucuk teh sebesar 650,082 $\mathrm{MJ} / \mathrm{ton}$, pelayuan sebesar 22.502,633 $\mathrm{MJ} / \mathrm{ton}$, penggilingan sebesar 4.808,636 $\mathrm{MJ} / \mathrm{ton}$, fermentasi sebesar 555,909 $\mathrm{MJ} / \mathrm{ton}$, pengeringan sebesar 17.451,726 MJ/ton, sortasi kering sebesar 20.840,587 MJ/ton, dan pengepakan sebesar $6.224,786 \mathrm{MJ} /$ ton.

Efisiensi penggunaan energi pada proses pelayuan adalah $17,5 \%$ sedangkan pada proses pengeringan adalah $21,2 \%$. Sehingga bisa disimpulkan bahwa proses pengeringan lebih efisien dari proses pelayuan.

Peluang penghematan energi dapat dilakukan dengan cara membersihkan mesin heat exchanger terutama bagian tungku dari debu sisa hasil pembakaran serta kebersihan pipa yang menyalurkan udara panas ke withering trough dan TSD agar terhindar dari debu atau kotoran.

\section{DAFTAR PUSTAKA}

Inayah, N. 2011. Audit Energi Pada Produksi Teh Hitam Ortodoks Di PTPN IX (Persero) Kebun Jolotigo, Pekalongan. Skripsi. Departemen Teknik Mesin dan Biosistem, Fakultas Teknologi Pertanian, IPB. Bogor.

Lembaga Ilmu Pengetahuan Indonesia. 2004. Pengembangan Energi Terbarukan Sebagai Energi Aditif di Indonesia. TGJ LIPI, Jakarta.

Pimentel, D. 1990. Handbook Of Energy For World Agriculture. Elsevier Science Publishing Co., INC. New York.

Rangkuti, F. 2004. Analisis SWOT Teknik Membedah Kasus Bisnis. PT. Gramedia, Jakarta.

Setiawan, T. 2010. Audit Energi Pada Sistem Pengolahan Pucuk Teh Menjadi Teh Hitam Orthodox di PT. Perkebunan Nusantara VIII Kebun Cisaruni, Garut Jawa Barat. Skripsi. Departemen Teknik Pertanian, Fakultas Teknologi Pertanian, IPB. Bogor. 